\title{
BIOCHRONOLOGY OF UPPERMOST CRETACEOUS AND LOWER TERTIARY NONMARINE MOLLUSCA OF THE NORTHERN GREAT PLAINS, U.S.A. AND CANADA
}

HARTMAN, Joseph H., Energy and Environmental Research Center, University of North Dakota, Box 8213, University Station, Grand Forks, ND 58202 U.S.A.

The biochronologic use of nonmarine mollusks commenced in the northern Great Plains with the pioneering studies of F.B. Meek and F.V. Hayden in the 1850 s and '60s. Their research focused on the chronostratigraphic organization of nonmarine and marine strata and included the naming of the Fort Union Group, which represents the Paleocene throughout the northern plains. Current research has focused on ascertaining the biostratigraphic distribution of nonmarine taxa throughout the post-Fox Hills Formation sections in the northern Great Plains, specifically in the Williston (WB: North Dakota, Montana, Saskatchewan), Powder River (PRB: Montana, Wyoming), and Crazy Mountains (CMB: Montana) Basins. The strata represented include the uppermost Cretaceous Lance (PRB) and Hell Creek (WB, PRB, CMB) Formations; Paleocene Fort Union Group, including (in ascending order) the Ludlow (WB)-Tullock (WB, PRB)-Bear (CMB), Slope (WB)-Lebo (PRB, CMB), Bullion Creek (WB)-Tongue River (WB, PRB)-Melville (CMB), and Sentinel Butte (WB) - lower "Wasatch" (PRB) Formations, and the Bear Den Member of the Golden Valley (WB) Formation; and the Lower Eocene Camels Butte Member of the Golden Valley Formation (WB) and main body of the "Wasatch" (PRB) Formation. About 2000 nonmarine molluscan localities have been collected from these strata and correlated with all of the approximately 200 relevant mammalian local faunas. The geologic section represented by each study area has a segment of the section that is biostratigraphically and biochronologically relatively well controlled by either molluscan or mammalian occurrences or both. These segments overlap sufficiently well to provide a nearly continuous composite section for the uppermost Cretaceous, Paleocene, and Lower Eocene. In the Montana portion of the Williston Basin, the uppermost Cretaceous (Lancian) taxon ranges of nonmarine mollusks and mammals are stratigraphically well controlled. Less abundant or less well-controlled occurrences elsewhere support the view that a diverse, molluscan assemblage, largely composed of highly sculptured unionid bivalves, is extinguished, relatively suddenly, near but before the end of the Cretaceous. The lower and lower middle Paleocene (Puercan and Torrejonian) section, as evidenced in isolated fossil occurrences, is a time of a substantially reduced number of low-diversity molluscan faunules consisting of a small mesogastropod-dominated snail fauna, a few taxa of which cross the Cretaceous-Tertiary boundary, and a small, unornamented (except for the umbonal region) fauna of unionids. The upper middle Paleocene (Torrejonian) and lower upper Paleocene (Tiffanian) contain a record indicating a resurgence in the molluscan fauna, particularly in the upland Paleocene terrains preserved in the upper Lebo and lower Melville Formations of the Crazy Mountains Basin. A relatively large number of localities contain a diversifying mesogastropoddominated snail fauna, an increasing number of terrestrial taxa, and an increasingly diversified, but unsculptured, unionid fauna. The middle upper Paleocene (Tiffanian 3-4) faunal record, representing the "classic" Fort Union molluscan fauna of Meek and Hayden, was comparatively diverse, abundant, and dominated by freshwater snail taxa. Although known from substantially fewer localities, this interval also contains an increase in diversity and novelty of aquatic and terrestrial pulmonates. Unionids are locally abundant, but remain relatively undiverse. The uppermost Paleocene (presumed Clarkforkian) record in the Powder River Basin documents a continued increase in pulmonate taxa and a sustained, but compositionally different, diversity of mesogastropods. The unionid fauna is relatively unchanged. The Paleocene-Eocene (Wasatchian) boundary, based on mammalian, palynomorph, and plant criteria, is clearly shown by a widespread change in the composition of the molluscan assemblage. The overall faunal diversity is somewhat reduced, with a noted reduction in the diversity of certain freshwater mesogastropods, a few unionid taxa, and a continued increase in the representation of pulmonate taxa. In summary, uppermost Cretaceous and lower Tertiary strata in the northern Great Plains contain a sequence of nonmarine molluscan faunas that are sufficiently diverse and changing so as to permit the construction of a substantially more resolved biochronology than previously considered possible. 